Perhaps the most striking difference in the habits of the two species is indicated by the fact that the eggs and larvæ obtained by Grossbeck were dug from open burrows and nothing was seen like a covered burrow. Emphor fuscojubatus very plainly makes use of the turret earth and even the ejected pellets for covering the nest not long after oviposition, leaving, however, a nearly circular depression somewhat like the impression of a finger tip in the sand.

That no bees were seen at Arlington after Sep. 3 may very well have been due to unfavorable weather conditions. At Cape May Point some were still active during the first week of September, but how much longer I do not know.

The death rate of the larvæ must be high, for from twenty-one cocoons preserved by Grossbeck he reports as emerging only one male and six females. This took place between July 11 and July 20, although on July 21 no bees were seen in the vicinity of the nesting site. Probably the time of emerging from the cocoon is nearly the same for $E$. fuscojubatus, although $I$ have as yet made no observations on this point.

\title{
ANTS COLLECTED IN GEORGIA BY DR. J. C. BRADLEY AND MR. W. T. DAVIS.
}

\section{By William Morton Wheeler.}

The following list is compiled from a large collection of ants made in different parts of Georgia by Dr. J. C. Bradley and a smaller collection made by Mr. W. T. Davis in a more restricted area. I have indicated the names of these collectors by their initials for each locality.

\section{Family Formicide. Subfamily Ponerince.}

1. Stigmatomma pallipes Haldem.-Clayton (J. C. B.); Black Rock Mt., Rabun Co. (W. T. D.).

2. Ponera trigona Mayr var. opacior Forel.-Gainesville and Billy's Island, Okefenokee Swamp (J. C. B.).

3. Ponera opaciceps Mayr.-St. Simon's Island (J. C. B.).

4. Ponera coarctata Latr. subsp. pennsylvanica Buckley.-Spring Creek, Burton, Thalman and Atlanta (J. C. B.). 
5. Odontomachus homatoda L. subsp. insularis Guérin.-Bainbridge, Ducker, Spring Creek and Billy's Island, Okefenokee Swamp (J. C. B.).

Subfamily Dorylino.

6. Eciton (Acamatus) opacithorax Emery.-Darien (J. C. B.); Clayton (W. T. D.).

\section{Subfamily Myrmicince.}

7. Pseudomyrma brunnea F. Smith.-Bainbridge, Cumberland, St. Simon's Island and Billy's Island, Okefenokee Swamp. (J. C. B.).

8. Pseudomyrma pallida F. Smith.-Spring Creek and Tybee Island (J. C. B.).

9. Pseudomyrma flavidula F. Smith.-Ogelthorpe and Billy's Island, Okefenokee Swamp (J. C. B.).

10. Myrmecina graminicola Latr. subsp. americana Emery.Gainesville (J. C. B.).

11. Myrmica scabrinodis Nyl. var. schencki Emery.-Clayton (W. T. D.).

12. Leptothorax bradleyi sp. nov.

Worker. Length $2.6 \mathrm{~mm}$.

Head rather large, subrectangular, a little longer than broad, with straight, parallel sides and feebly excised posterior border. Eyes rather small, at the middle of the sides of the head. Mandibles and clypeus moderately convex, the latter with straight, entire anterior border. Frontal area small and indistinct. Antennæ 11-jointed; scapes reaching half way between the eyes and the posterior corners of the head; funiculi with a 3-jointed club; first funicular joint as long as the three succeeding joints together; joints 2-6 much broader than long, joint 7 as long as broad; terminal joint longer than the two penultinate joints together. Thorax rather robust, narrower than the head, broader in front than behind, but as high behind as in front, with flattened dorsal and lateral surfaces and rather angular humeri, without any traces of a mesoëpinotal constriction. Epinotal spines stout, as long as broad at their bases, laterally compressed, suddenly tapering at their tips, directed backward and slightly upward, further apart at their bases than long. Petiole from above about $1 \frac{1}{2}$ times as long as broad, pyriform, with rounded sides; its node in profile with feebly concave anterior and decidedly convex posterior slopes, meeting with a distinct transverse ridge, the lower border in profile feebly concave and with a small, compressed anterior tooth. Postpetiole from above transversely elliptical, slightly broader than the petiole, slightly broader than long, in profile smaller than the petiole, as long as high, with evenly rounded, convex node. Gaster elongate elliptical, its sides rather straight, its anterior border excised in the middle. Legs stout, with incrassated femora. 
Head, including the mandibles, thorax, petiole, postpetiole and antennæ opaque; gaster and legs shining. Mandibles finely longitudinally striated. Clypeus coarsely longitudinally rugose, on the sides reticulately rugose. Head above and on the sides finely and evenly longitudinally rugose, with the interrugal spaces reticulate-punctate. Thorax, petiole and postpetiole densely punctate, the thorax also reticulately and longitudinally rugose both on the dorsal and pleural surfaces.

Hairs yellowish, short and rather abundant, clavate and erect on the head, thorax and abdomen, appressed and pointed on the legs and scapes.

Color ferruginous red; antennæ, legs and gaster, except the posterior borders of the segments, somewhat paler; mandibular teeth black.

Described from a single specimen taken by Mr. J. C. Bradley on Billy's Island in the Okefenokee Swamp.

In the shape of the body and in coloration, this species is very similar to L. schaumi Roger, but differs in the much coarser, longitudinal rugosity of the head and thorax, much larger and differently shaped epinotal spines and in the shape of the petiolar node, the sides and posterior declivity of which are much more convex and rounded. From L. fortinodis Mayr., bradleyi differs in these same characters, except the shape of the petiole, and in the paler coloration.

13. Leptothorax curvispinosus Mayr.-Atlanta and Clayton (J. C. B).

14. Leptothorax (Dichothorax) pergandei Emery.-Atlanta(J. C. B.).

15. Pogonomyrmex badius Latr--Bower Station, Albany, Bainbridge, Spring Creek, Tybee Island, St. Simon's Island and Billy's Island, Okefenokee Swamp (J. C. B.).

16. Aphœnogaster lamellidens Mayr.-Gainesville, Spring Creek and Thunderbolt (J. C. B.).

17. Aphonogaster treate Forel.- Tallulah Falls, Clayton and Black Rock Mt., 2000-3500 ft. (J. C. B.).

18. Aphonogaster treatee Froel var. ashmeadi Emery.-Atlanta and St. Simon's Island.

19. Aphœnogaster fulva Roger.-Black Rock Mt., Spring Creek and Gainesville (J. C. B.).

20. Aphønogaster fulva Roger subsp. aquia Buckley.-Summerville, Tallulah Falls, Clayton, Atlanta, Black Rock Mt., and Billy's Island, Okefenokee Swamp (J. C. B.).

21. Aphonogaster tennesseensis Mayr.-Clayton (J. C. B. and W. T. D.). 
22. Monomorium minimum Buckley.-Cave Springs, Spring Creek, Atlanta, Thunderbolt and Billy's Island, Okefenokee Swamp (J. C. B.).

23. Monomorium pharaonis L.-Albany (J. C. B.).

24. Crematogaster ashmeadi Mayr.-Gainesville and Atlanta (J. C. B.).

25. Crematogaster lineolata Say.-Oglethorpe, and Billy's Island, Okefenokee Swamp, Atlanta (J. C. B.).

26. Crematogaster lineolata Say var. lutescens Emery.-Athens, St. Simon's Island, Tallula Falls, Gainesville, Fitzgerald and Billy's Island, Okefenokee Swamp (J. C. B.).

27. Crematogaster lineolata Say var. near lutescens Emery.-Tallulah Falls, Spring Creek, Black Rock Mt. and Gainesville (J. C. B.).

28. Crematogaster lineolata Say var. subopaca Emery.-Black Rock Mt. (J. C. B.).

29. Crematogaster lineolata Say subsp. subpilosa Pergande.Clayton, 2000-3500 ft. (W. T. D.).

30. Solenopsis geminata Fabr.-St. Simon's Island, Spring Creek,

Waycross and Billy's Island, Okefenokee Swamp (J. C. B.).

31. Pheidole vinelandica Forel.-Clayton and Gainesville (W. T. D.).

32. Pheidole tysoni Forel-—Tallulah Falls (J. C. B.); Clayton (W. T. D.).

33. Pheidole metallescens Emery.-Thunderbolt and St. Simon's Island (J. C. B.).

34. Pheidole dentata Mayr.-Cornelia (W. T. D.).

35. Pheidole dentata Mayr. var. faisonica Forel.-Tallulah Falls (J. C. B.).

36. Pheidole dentata Mayr. var.-St. Simon's Island, Tybee Island, Gainesville and Spring Creek (J. C. B.).

37. Pheidole crassicornis Emery.-Bainbridge (J. C. B.).

38. Pheidole crassicornis Emery var.-Black Rock Mt. (J. C. B.). 39. Atta (Trachymyrmex) septentrionalis MacCook.-Bainbridge and Spring Creek (J. C. B.).

\section{Subfamily Dolichoderino.}

40. Dolichoderus (Hypoclinea) mario Forel.-Toccoa and Clayton (J. C. B.). 
41. Dolichoderus (Hypoclinea) pustulatus Mayr. var. beutenmuelleri Wheeler.-Cornelia (W. T. D.).

42. Dorymyrmex pyramicus Roger--Atlanta, Ducker and Gainesville (J. C. B.).

43. Dorymyrmex pyramicus Roger var. flavus MacCook.-Spring Creek, Gainesville, Thunderbolt and Atlanta (J. C. B.).

44. Iridomyrmex pruinosus Roger.-Tybee Island, Savannah and Billy's Island, Okefenokee Swamp (J. C. B.).

45. Iridomyrmex pruinosus var. analis Ern. André.-Atlanta and Gainesville (J. C. B.).

46. Tapinoma sessile Say.-Waycross and Spring Creek (J. C. B.).

Subfamily Camponotinœ.

47. Prenolepis imparis Lay.-Clayton, 2000-3700 ft. (W. T. D.).

48. Prenolepis imparis Lay var. testacea Emery.-Gainesville. Tybee Island, Marietta and Atlanta (J. C. B.).

49. Prenolepis (Nylanderia) longicornis Latr. Bainbridge; "a very annoying pest and excessively abundant” (J. C. B.).

50. Prenolepis (Nylanderia) arenivaga Wheeler.-Spring Creek (J. C. B.).

51. Prenolepis (Nylanderia) vividula Nyl.-Gainesville and Billy's Island, Okefenokee Swamp (J. C. B.).

52. Lasius niger L. var. americanus Emery.-Gainesville and Tybee Island (J. C. B.).

53. Lasius (Acanthomyops) murphyi Forel-Clayton (J. C. B.).

54. Lasius (Acanthomyops) interjectus Mayr--Gainesville (J. C. B.).

55. Formica truncicola Nyl. subsp. integra Nyl.-Atlanta and Stone Mt. (J. C. B.).

56. Formica truncicola Nyl. subsp. obscuriventris Mayr.-Clayton (W. T. D.).

57. Formica difficilis Emery var.-Clayton (W. T. D.).

58. Formica fusca L. var. subsericea Say.-Black Rock Mt. and Spring Creek (J. C. B.).

59. Formica (Neoformica) pallidefulva Latr.-Tallulah Falls, Marietta, Ducker, Clayton, Clarkesville, Atlanta and Black Rock Mt. (J. C. B.).

60. Formica (Neoformica) pallidefulva Latr. subsp. schaufussi Mayr.-Black Rock Mt. (J. C. B.). 
61. Formica (Neoformica) pallidefulva Latr. subsp. schaufussi Mayr. var. dolosa Wheeler-Clayton (W. T. D.).

62. Formica (Neoformica) pallidefulva Latr. subsp. nitidiventris Emery var. fuscata Emery-Thunderbolt and Savannah (J. C. B.).

63. Camponotus socius Roger.-Spring Creek, Ducker and Darien (J. C. B.).

64. Camponotus abdominalis Roger subsp. floridanus Buckley.Bainbridge, Brunswick, St. Simon's Island, Tybee Island, Spring Creek, Honey Island and Billy's Island, Okefenokee Swamp (J. C. B.); St. Mary's (O. Bangs).

65. Camponotus castaneus Latr.-Tallulah Falls and Waycross (J. C. B.).

66. Camponotus castaneus Latr. subsp. americanus Mayr.Summerville, Black Rock Mt. and Billy's Island, Okefenokee Swamp (J. C. B.).

67. Camponotus herculeanus L. subsp. pennsylvanicus DeGeer.Clayton (W. T. D.); Bainbridge, Summerville, Vienna, Cave Springs, Spring Creek and Blackspear (J. C. B.).

68. Camponotus herculeanus L. subsp. pennsylvanicus DeGeer var.-Gainesville (J. C. B.).

69. Camponotus fallax $\mathrm{Nyl}$. var. nearcticus Emery.-Burton, Clayton and Billy's Island, Okefenokee Swamp (J. C. B.).

70. Camponotus fallax Nyl. subsp. discolor Emery.- "Georgia” (J. C. B.).

71. Camponotus fallax Nyl. var. near. decipiens Emery.-Athens (J. C. B.); Clayton, 2000-3700 ft. (W. T. D.).

72. Camponotus (Colobopsis) impressus Roger.--Spring Creek and St. Simon's Island (J. C. B.). 

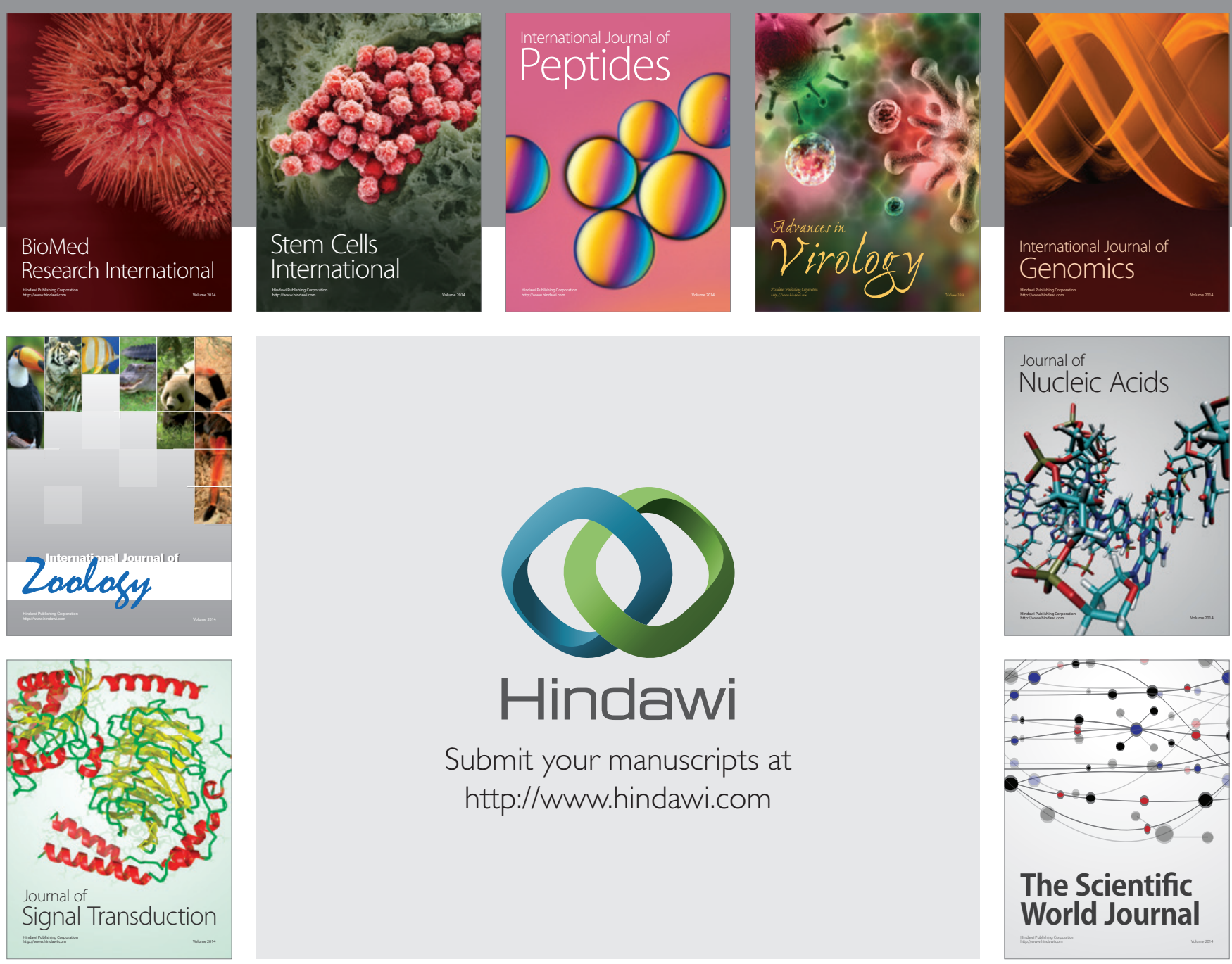

Submit your manuscripts at

http://www.hindawi.com
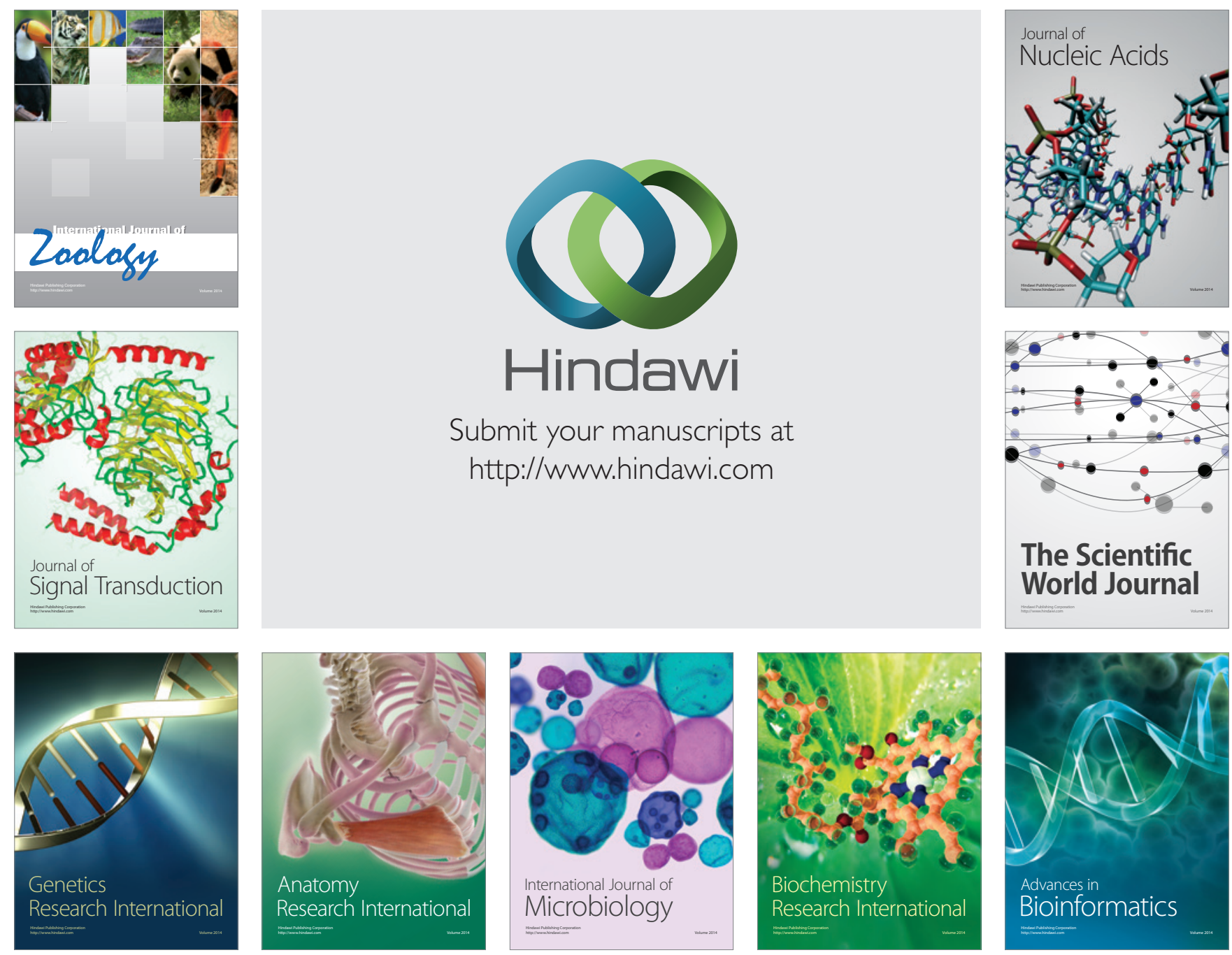

The Scientific World Journal
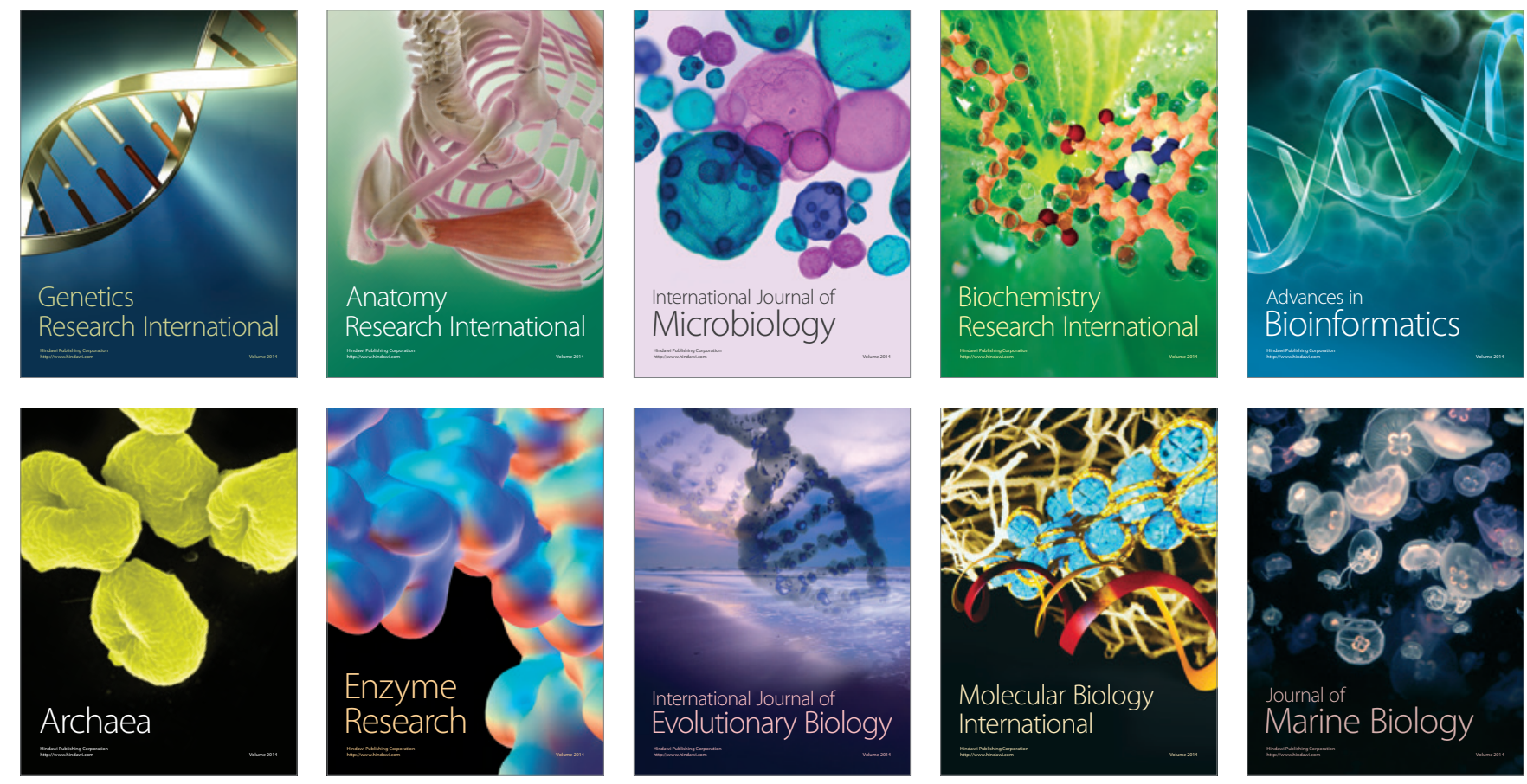